\title{
Determinant of Neighboring Migrant Workers to Thailand
}

\author{
Thitiwan Sricharoen
}

\begin{abstract}
This paper has purpose to analyze the determinant of migration classified by nationality, Burmese, Cambodian and Laotian migrants. A total of 511 migrants separated into 211 Burmese, 150 Cambodian and 150 Laotian. Analytical tool is logistic regression analysis. The results indicate that determinant of migrant worker to migrate are income before migration of labor, knowledge and attitude toward destination, having own house at home, number of family member living in destination country, difficulties in finding work at home, and career achievement opportunities at home. Variables that have positive relation with demand on migration are income before migration of labor, knowledge and difficulties in finding work at home. Variables that the coefficients of them have negative relation with demand on migration are attitude toward destination, having own house at home, number of family member living in destination country, and career achievement opportunities at home.
\end{abstract}

Index Terms - International migration, burmese migrant, cambodian migrant, laotian migrant.

\section{INTRODUCTION}

The phenomenon of millions of people emigrates overseas for many centuries. Since the 1970s, the industrial revolution has attracted the world's attention of migration. Million migrants left home and most of them headed for the more developed countries, particularly those in North America. However, a new phenomenon has coned to be visible since late the $20^{\text {th }}$ century. More and more migrant are heading for the developing countries in Southeast Asia, Latin America, and Africa.

The number of international migrants worldwide has continued to grow rapidly in recent years, reaching 258 million in 2017, up from 220 million in 2010 and 173 million in 2000. Over 60 percent of all international migrants live in Asia (80 million) or Europe (78 million). In 2017, two thirds (67 percent) of all international migrants were living in just twenty countries. Of the twenty largest countries of destination of international migrants worldwide, nine are located in Asia, seven in Europe, two in Northern America, and one each in Africa and Oceania (Fig. 1) (United Nation, 2017).

Large numbers of people entered and settled into Asia. Southeast Asia is one of the region's main destinations. Migration in Southeast Asia has a dramatically increased. The number of international migrants flow to this region was reached to double in 2017, up from 4.9 million in 2000. About 9.8 million people are living outside their birth country driven by hope, to enhance the living standards; particularly high skilled workers take migration into account. In 2017, the

Manuscript received January 20, 2020; revised April 3, 2020.

Thitiwan Sricharoen is with the Faculty of Economics, Kasetsart University, Sriracha campus, Sukhumvit Road, Tungsukha, Sriracha District, Chonburi, Thailand 20230 (e-mail: thitiwanthitiwan@gmail.com). age of international migrants in Southeast Asia was 35 years, a highly increase from 29 years in 2000. In this region, the migrant population is becoming older. Even though Southeast Asia contain of many countries, Thailand has received the largest immigration flows. The migrants are poor people; poor educated and speak only their own language, from neighboring countries. They are looking for their livelihood abroad (Table I).

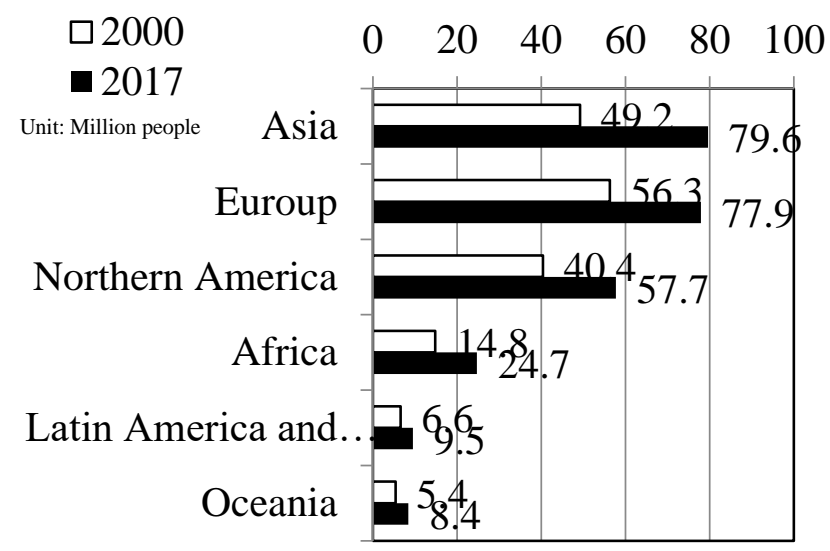

Fig. 1. Number of international migrants (million) by region of destination, 2000 and 2017. Source: United Nations (2017) [1].

TABLE I: DESTINATION OF MIGRANTS IN SOUTHEAST ASIA

\begin{tabular}{lcccccc}
\hline $\begin{array}{c}\text { Destin } \\
\text { ation } \\
\text { (down) }\end{array}$ & $\begin{array}{c}\text { Number of } \\
\text { International } \\
\text { Migrants } \\
\text { (Thousands) }\end{array}$ & $\begin{array}{l}\text { Internationa } \\
\text { I Migrants } \\
\text { as } \\
\text { Percentage } \\
\text { of Total } \\
\text { Population }\end{array}$ & $\begin{array}{c}\text { Median Age of } \\
\text { International } \\
\text { Migrants } \\
\text { (Years) }\end{array}$ \\
\hline Southeast & 4,92 & 9,87 & 0.9 & 1.5 & 29.4 & 34.5 \\
Thailand & $\mathbf{1 , 2 5}$ & $\mathbf{3 , 5 8}$ & $\mathbf{2 . 0}$ & $\mathbf{5 . 2}$ & $\mathbf{3 3 . 7}$ & $\mathbf{3 5 . 8}$ \\
Malaysia & 1,27 & 2,70 & 5.5 & 8.5 & 17.9 & 34.9 \\
Singapore & 1,35 & 2,62 & 34.0 & 46.0 & 25.5 & 29.8 \\
Indonesia & 292 & 346 & 0.1 & 0.1 & 29.5 & 36.8 \\
Philippines & 318 & 219 & 0.4 & 0.2 & 27.6 & 33.0 \\
Brunei & 96 & 109 & 28.9 & 25.3 & 31.7 & 36.9 \\
Cambodia & $\mathbf{1 4 6}$ & $\mathbf{7 6}$ & $\mathbf{1 . 2}$ & $\mathbf{0 . 5}$ & $\mathbf{3 1 . 0}$ & $\mathbf{3 4 . 0}$ \\
Vietnam & 57 & 76 & 0.1 & 0.1 & 37.0 & 39.4 \\
Myanmar & $\mathbf{9 8}$ & $\mathbf{7 5}$ & $\mathbf{0 . 2}$ & $\mathbf{0 . 1}$ & $\mathbf{2 6 . 1}$ & $\mathbf{3 3 . 5}$ \\
Lao PDR & $\mathbf{2 2}$ & $\mathbf{4 5}$ & $\mathbf{0 . 4}$ & $\mathbf{0 . 7}$ & $\mathbf{2 9 . 7}$ & $\mathbf{3 7 . 1}$ \\
Timor-Leste & 11 & 12 & 1.2 & 0.9 & 27.2 & 36.5 \\
\hline \hline
\end{tabular}

Source: United Nation, 2017, page 27 [1].

The influx of the overseas emigrants to Thailand began for long. The major influx into western Thailand comes from Myanmar. The migration flow into northeastern Thailand comes from Lao PDR and the main route of migration into eastern Thailand comes from Cambodia. Migration to Thailand has intensified. Thailand now hosts approximately 4.9 million non-Thai residents, a substantial increase from 3.7 million in 2014. Most of them come from neighbouring 
Cambodia, Lao People's Democratic Republic, Myanmar and Viet Nam, accounting for an estimated 3.9 million documented and undocumented migrant workers. Other major groups include an estimated 480,000 stateless persons, 110,000 skilled professionals and 100,000 refugees and asylum seekers (United Nation, 2019) [2].

Major destination for neighboring countries is Thailand. In 2017, there were more than 1.8 million Burmese people, nearly a million of Laotian people and a half million of Cambodian people, migrate to Thailand. A vast majority of immigrants settled in central region including Samutsakorn, Samutpakarn, and Nakornprathom province. These provinces received more than half of all immigrants in Thailand.

TABLE II: TOP TEN DESTINATION OF MIGRANT FROM MYANMAR, CAMBODIA, LAO AND THAILAND IN 2017

\begin{tabular}{|c|c|c|c|}
\hline \multirow[b]{2}{*}{$\begin{array}{l}\text { Destination } \\
\text { (down) }\end{array}$} & \multicolumn{2}{|l|}{$\begin{array}{c}\text { Source } \\
\text { country }\end{array}$} & \multirow{2}{*}{$\begin{array}{c}\begin{array}{c}\text { Source } \\
\text { country }\end{array} \\
\text { Cambodia }\end{array}$} \\
\hline & Myanmar & Destination & \\
\hline Thailand & $1,835,106$ & Thailand & 750,109 \\
\hline Malaysia & 308,337 & United States & 152,415 \\
\hline Saudi Arabia & 242,510 & France & 64,306 \\
\hline Bangladesh & 239,742 & Australia & 36,920 \\
\hline United States & 142,494 & Canada & 27,618 \\
\hline India & 50,081 & Bangladesh & 20,109 \\
\hline China & 39,776 & Malaysia & 17,226 \\
\hline Australia & 32,540 & Korea, Rep. & 14,550 \\
\hline Vietnam & 11,695 & New Zealand & 7,007 \\
\hline United & 10,710 & Lao PDR & 3,568 \\
\hline \multicolumn{3}{|c|}{ Source } & Source \\
\hline Destination & Lao PDR & Destination & Thailand \\
\hline Thailand & 926,427 & United States & 253,585 \\
\hline United States & 183,894 & Malaysia & 93,635 \\
\hline Bangladesh & 90,253 & Australia & 72,250 \\
\hline France & 43,524 & Germany & 61,000 \\
\hline Canada & 16,631 & Japan & 47,047 \\
\hline Australia & 11,660 & United Kingdom & 41,353 \\
\hline Vietnam & 7,272 & Sweden & 38,792 \\
\hline Germany & 3,606 & Korea & 34,372 \\
\hline China & 1,373 & Cambodia & 31,791 \\
\hline Belgium & 1,146 & $\begin{array}{l}\text { Brunei } \\
\text { Darussalam }\end{array}$ & 25,451 \\
\hline
\end{tabular}

Source: World Bank, 2018 [3].

Table II illustrates the Bilateral Migration Matrix in 2017. Migrants from Cambodia, Lao, and Myanmar were 79 percent out of 4.4 million inflow migrants to Thailand. Within this number, Myanmar is as the greatest source of migrant country, about 1.8 million, follows by Lao and Cambodia. Table III compares the bilateral estimates of migrant stocks in 2017. It is interesting that people around the world migrate to Myanmar around 103 thousand persons, mostly from China and India, whereas there is no any people from Cambodia, Lao and Thailand migrate to Myanmar. Surprisingly, there is a great number of Thai people migrate to Cambodia. In the last column, out of a total of 266 million migrant people around the world, the Burmese migrate to around the world account for 2.9 million, followed by Laotian people with 1.3 million and Cambodian people with 1.1 million.

Migrant workers travel cross the border to Thailand. There are both legal and illegal migrant. The legal migrants have two main processes to facilitate, the MOUs and NV processes. The first is through the memoranda of understanding (MOUs) with neighboring Cambodia, Lao PDR, Myanmar and Viet Nam, which provide migrants a fully legal channel to access job opportunities in Thailand. The second approach is through the registration system known as the nationality verification (NV) process, which allows undocumented migrants to regularize their status without having to return to their countries of origin. The NV process begins for migrants by registering for an identification card at One Stop Service Centers (United Nation, 2019)[2]. On September 2018, three nationality of migrant worker in Thailand were about 2 million, mainly from Myanmar, Cambodia and Lao. Most type of migrant worker was NV type, about 1.3 million. Most Burmese migrant were NV type, while Cambodian and Laotian migrant were MOUs type. It was interesting that ratio of employee per employer was five times. In addition, only half of the registered migrant participate Thailand social security fund. Therefore, it can be implied that half of them are vulnerability. Many migrants dare to take the risk to immigrate to Thailand although it is the irregular ways normally through the international human smuggling network (Table IV).

TABLE III: BILATERAL ESTIMATES OF MIGRANT STOCKS IN 2017

\begin{tabular}{|c|c|c|c|c|c|c|}
\hline \multicolumn{7}{|c|}{ Destination Country (across) } \\
\hline $\begin{array}{l}\text { Source } \\
\text { country } \\
(\text { down) }\end{array}$ & Cambodia & $\%$ & Lao & $\%$ & Myanmar & $\%$ \\
\hline Cambodia & 0 & 0.0 & 3,568 & 7.8 & 0 & 0 \\
\hline Lao & 268 & 0.4 & 0 & 0.0 & 0 & 0 \\
\hline Myanmar & 53 & 0.1 & 282 & 0.6 & 0 & 0 \\
\hline Thailand & 31,791 & 41.6 & 3,428 & 7.5 & 0 & 0 \\
\hline Total & 32,112 & & 7,278 & & 0 & \\
\hline World & 76,333 & 42.1 & 45,489 & 16 & 103,380 & - \\
\hline \multicolumn{7}{|c|}{ Destination country } \\
\hline Source & Thailand & $\%$ & World & $\%$ & & \\
\hline Cambodia & 750,109 & 9 & $1,114,226$ & 0.4 & & \\
\hline Lao & 926,427 & 20.9 & $1,292,295$ & 0.5 & & \\
\hline Myanmar & $1,835,106$ & 41.3 & 2,947,287 & 1.1 & & \\
\hline Thailand & 0 & 0.0 & 993,253 & 0.4 & & \\
\hline Total & $3,511,642$ & & $6,347,061$ & & & \\
\hline World & $4,438,567$ & 79.1 & $266,143,792$ & & & \\
\hline
\end{tabular}

Source: World Bank, 2018 [3].

Note: Data on April 2018. World Bank staff estimates based on UN Population Division, OECD, the Australian Bureau Statistics, the German Federal Statistical Office, the UK Office of National Statistics, and the US Census Bureau. See World Bank Migration and Remittances Fact book 2016 for definitions, data sources, and 2013 estimates. \% is the percentage of migrants compare to world migration.

TABLE IV: MIGRANT WORKER IN THAILAND, DATA ON SEPTEMBER 2018

\begin{tabular}{|c|c|c|c|c|c|}
\hline \multirow{2}{*}{$\begin{array}{l}\text { Type of } \\
\text { migrant } \\
\text { worker }\end{array}$} & \multirow[b]{2}{*}{ Employer } & \multicolumn{3}{|c|}{ Migrant Worker } & \multirow[b]{2}{*}{ Total } \\
\hline & & Myanmar & Cambodia & Lao & \\
\hline \multicolumn{6}{|c|}{ Nationality verification (NV) Type } \\
\hline & 364,943 & $1,038,584$ & 165,480 & 95,15 & $1,299,221$ \\
\hline \multicolumn{6}{|c|}{ Memoranda of understanding (MOUs) type } \\
\hline & 105,421 & 385,011 & 298,045 & 144,9 & 828,032 \\
\hline \multicolumn{6}{|c|}{ Total 3 nationalities migrants } \\
\hline & 470,364 & $1,423,595$ & 463,525 & 240,1 & $2,127,253$ \\
\hline \multicolumn{6}{|c|}{ Migrants who join the social security fund } \\
\hline & & 789,372 & 266,454 & 50,87 & $1,106,703$ \\
\hline Percent & & 55.45 & 57.48 & 21.19 & 52.02 \\
\hline
\end{tabular}

Source: Foreign Workers Administration Office, 2018. [4]

Although migrant workers face numerous problems both expected and unexpected problem, they are still having the incentive to migrate to Thailand. The choice to migrate is usually a difficult one, and for many, the difficulties continue 
throughout the migration process. The vast majority of migrants are doing dirty, difficult, and dangerous (3D) work, the living conditions are often poor, and migrants are generally not welcomed or well treated in the host country. Language and cultural barriers further compound these difficulties and contribute to the marginalization of migrants and migrant communities in many countries around the world (ADB, 2009) [5]. When the migrants start a new life aboard, many migrants have numerous conflicting emotions towards what living in a new environment might bring. An understanding of the causes and consequences of migration is essential, both for addressing the management of effective programs to assist the migrants and also necessary to improve international coordination.

\section{SOURCES OF DATA}

This is a cross sectional study involving 511 migrant workers at labor force ages extracted from the migrant workers who participate the legally migrant worker registration at One Stop Service center, Chonburi province, Thailand. Data was collected in 2018. Data sampling apply purposive sampling technique. Data on some selected important socioeconomic, demographic and migration related characteristics have been collected using direct interview method at the time of survey.

\section{Methodology}

This study presents descriptive statistics and logistic regression analysis. Descriptive statistics uses to analyze the patterns of important socioeconomic, demographic and migration related characteristics, and the logistic regression analysis has been applied to identify factors of migration to Thailand. The logistic model was developed by Walker and Duncun (1967) [6]. The logistic regression model can be employed to explore migration factors and also to predict the probability of migration. The model is widely used to identify the influence of various socioeconomic and demographic characteristics for controlling the effect variables on the likelihood of the occurrence of the event of interest. In logistic model, a migrant who has a willingness to migrate in the future as dependent variable which is dummy variable and it is classified in the following way:

$\mathrm{Y}=1$, if the migrant worker has demand on migration.

$\mathrm{Y}=0$, if the migrant worker doesn't has demand on migration.

The explanatory variables that are used in this model are explained as the bellowing equation.

$$
\operatorname{Pr}(Y=1)=\frac{1}{1+e^{-x}}
$$

$Y=\beta_{0}+\beta_{1} S E X+\beta_{2} A G E+\beta_{3} E D U+\beta_{4} D E B T+$

$\beta_{5}$ STATUS $+\beta_{6}$ UNEMPLOY $+\beta_{7}$ INCOME $E_{t-1}+\beta_{8} I N C O M E+$

$\beta_{9}$ EMPLOYRT $+\beta_{10}$ ATTITUDE $+\beta_{11}$ OWNHOUSE +

$\beta_{12}$ FAMMEMB $+\beta_{13}$ DIFFICULT $+\beta_{14}$ UNEMPLOY $_{t-1}+$

$\beta_{15}$ DRYWEAT $+\beta_{16}$ POOR $+\beta_{17}$ LOWINCOM $+\beta_{18}$ POLITIC +

$\beta_{19}$ OPPORTU $+\beta_{20}$ WELFARE $+\beta_{21}$ DISTANCE $+\beta_{22}$ DIFINCOM +

$\beta_{23}$ POPDENS $+\beta_{24}$ AREA $+\beta_{25}$ NONFARM $+\beta_{26}$ GETJOB $+\varepsilon_{t}$
Personal factors:

1.SEX

2.AGE

3.EDU

4.DEBT

5.STATUS

6.UNEMPLOY

7.INCOME $\mathrm{I}_{\mathrm{t}-1}$

8.INCOME

9.EMPLOYRT

Gender

Age

Educational level

Debt

Marital status

Unemployment of labor

Income before migration of labor

Present income of labor

Ratio of employed worker to total family members

10.ATTITUDE Knowledge and attitude toward destination

11.OWNHOUSE Having own house at home

12.FAMMEMB Number of family member living in destination country

Factors relate to home country:

13.DIFFICULT Difficulties in finding work at home

14.UNEMPLOY $\mathrm{t}_{\mathrm{t}-1}$ The unemployment of worker at home

15.DRYWEAT Arid climate that is not favorable for agriculture at home

16.POOR Difficulties and poverty at home

17.LOWINCOM Low wage level at home country

18.POLITIC Unstable social and political at home

19.OPPORTU Career achievement opportunities at home

20.WELFARE Welfare and public utilities at home

Factors relate to destination country:

21.DISTANCE Distance between home and destination country

22.DIFINCOM Income difference between destination and home country

23.POPDENS Population density between destination and home country

24.AREA Area size ratio between destination and home country

25.NONFARM Working on non farm sector at destination country

26.GETJOB Having a work position at destination country

$\varepsilon_{i}$

Random error term

\section{RESULTS}

\section{A. Descriptive Analysis}

The descriptive analysis consist of the distribution of socioeconomic, demographic and migration related characteristics of migrant workers. It is observed that migrants are significantly 30 aged, more likely to be women and considerably graduate primary education. The analysis shows up that the migrants are more likely to be married and be employed. An increase of relative income of a migrant compared to prior migration by $235 \%$ (from 2,850 Baht per month to 9,554 Baht per month). So, all people who find more attractive income in other country are likely to migrate. The ratio of working family member to total family member is $75 \%$. The majority of them do not have own house at home country.

The significant influence of number of family member living abroad is important for migration analysis. Most migrants have an average of three persons in their family living aboard. They mostly had background about the 
difficulties to find work at home country. The average unemployment rates of the studied countries are about 3 percent. Most migrants give the view that dry weather and welfare in the country of origin do not have affected on migration. However, they give an opinion that poverty situation at home, low wage, unstable social and politic, working opportunities have influenced on decision.

\begin{tabular}{|c|c|c|}
\hline & Mean $(\mathrm{N}=511)$ & $\begin{array}{r}\text { Std. } \\
\text { Deviati }\end{array}$ \\
\hline Gender & Female & 0 \\
\hline Age & 30 years & 9 \\
\hline Education & Primary school & 1 \\
\hline Debt of migrant worker & 2,078 Baht & \\
\hline Status & Married & \\
\hline Be unemployment & No & \\
\hline Income before migration & 2,850 Baht/month & \\
\hline Income after migration & 9,554 Baht/month & \\
\hline $\begin{array}{l}\text { Ratio of working family member to } \\
\text { total member }\end{array}$ & 75 percent & 26 \\
\hline $\begin{array}{l}\text { Knowledge and attitude to } \\
\text { destination }\end{array}$ & High & 1 \\
\hline Have own house at home country & No & 0 \\
\hline Family members living aboard & 3 persons & 2 \\
\hline $\begin{array}{l}\text { Difficulties to find work at home } \\
\text { country }\end{array}$ & Yes & 0 \\
\hline Unemployment rate at home country & 3 percent & 2 \\
\hline Dry weather not suit for farm work & No & 0 \\
\hline Hard and poor at home country & Yes & 0 \\
\hline $\begin{array}{l}\text { Low wage at home country compare } \\
\text { to destination }\end{array}$ & Yes & 0 \\
\hline Unstable social and Politic & Yes & 0 \\
\hline $\begin{array}{l}\text { Working opportunity in Country of } \\
\text { origin }\end{array}$ & High & 1 \\
\hline $\begin{array}{l}\text { Welfare and facilities in Country of } \\
\text { origin }\end{array}$ & No & 0 \\
\hline $\begin{array}{l}\text { Average distance between Thailand } \\
\text { by country of origin }\end{array}$ & $865 \mathrm{kms}$ & 234 \\
\hline $\begin{array}{l}\text { Difference of income between host } \\
\text { and home country }\end{array}$ & 6,704Baht/month & 5,406 \\
\hline $\begin{array}{l}\text { Population density of Thailand } \\
\text { divided by country of origin }\end{array}$ & 0.35 people $/ \mathrm{km}^{2}$ & 0 \\
\hline $\begin{array}{l}\text { Ratio of area between Thailand by } \\
\text { country of origin }\end{array}$ & 2 times & 1 \\
\hline $\begin{array}{l}\text { Migrant labor who work in nonfarm } \\
\text { sector }\end{array}$ & Yes & 0 \\
\hline $\begin{array}{l}\text { Have working position immediately } \\
\text { migration }\end{array}$ & Yes & 0 \\
\hline
\end{tabular}

In addition, average distance between home and host country is about 856 kilometers. Difference of income between host and home country is about 6,704 Baht per month. In 2017, population density in Myanmar was 53.37 people $/ \mathrm{km}^{2}$, Cambodia was 16.01 people $/ \mathrm{km}^{2}$, Lao was 6.86 people $/ \mathrm{km}^{2}$, and Thailand was 69.04 people $/ \mathrm{km}^{2}$. Ratio of population density of Myanmar to Thailand was 0.77 people $/ \mathrm{km}^{2}$, Cambodia to Thailand was at 0.23 people $/ \mathrm{km}^{2}$ and Lao to Thailand was 0.1 people $/ \mathrm{km}^{2}$. Finally, migrants are more likely to get nonfarm work and they mostly get work immediately arrived (Table V).

\section{B. Determinant of Migration Demand}

Determinant of demand on migration is the analysis of the relationship of independent and dependent variables by Binary Logistic Model. Table VI represents the classification table of determination of labor migration. It is the checking of the confidential of the forecast of step 0 , which means that there is only the constant. From the data, 289 migrants are not likely to migrate. When use the equation that have only constant, it forecasts that the percentage corrected of the nondemand on migration group is at $78.9 \%$. On the other hand, there are 222 migrants are likely to migrate. When apply the equation that has only constant value to forecast. It forecasts that demand to migrate in the future is correct at $69.8 \%$. Therefore, the average percentage corrected of the model is $75 \%$ (Table VI).

TABLE VI: CLASSIFICATION TABLE OF DETERMINANTS OF LABOR MIGRATION

\begin{tabular}{lcccc}
\hline \hline & \multicolumn{3}{c}{ Predicted } \\
\cline { 2 - 4 } & & $\begin{array}{c}\text { Demand to migrate in the } \\
\text { future }\end{array}$ & $\begin{array}{c}\text { Percentag } \\
\text { e Correct }\end{array}$ \\
\cline { 2 - 3 } Observed & Yes & 155 & 67 & 69.8 \\
\hline Demand on & No & 61 & 228 & 78.9 \\
Migration & & & 75.0 \\
\hline Overall & & & \\
\hline \hline Source: Own calculation. & & \\
Note: Constant is included in the model. The cut value is 0.5.
\end{tabular}

Table VII describes the regression function written in equation 3 . The table also includes the test of significance of each of the coefficients in the logistic regression model. Wald statistic is basically t2 which is Chi-Square distributed with $\mathrm{df}=1$. Sig. is the significance levels of each coefficient.

There are 3 factors influencing of migration demand that are: 1) Personal factor, 2) Factors relating to country of origin, and 3) Factors relating to destination country. Looking at the table as a whole, only INCOME $_{\mathrm{t}-1}$, ATTITUDE, OWNHOUSE, FAMMEMB, DIFFICULT, OPPORTU variables are significant, all other variables are not.

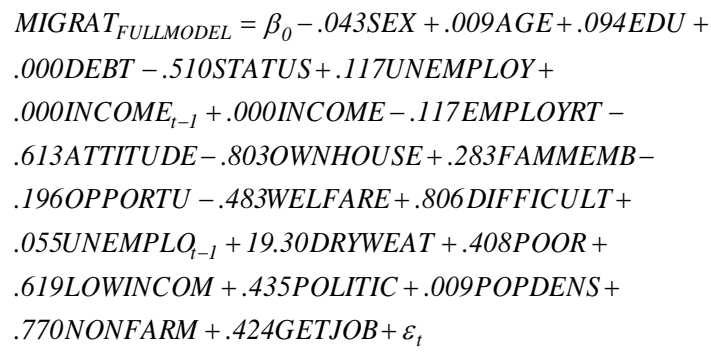

Considering to the coefficient value of the fitted variables, variables that have positive relation with demand on migration are NCOMEt-1, FAMMEMB, DIFFICULT. Independent variables that the coefficients of them have negative relation with demand on migration are ATTITUDE, OWNHOUSE, OPPORTU variables (Table VII)

TABLE VII: FULL MODEL OF VARIABLES IN THE EQUATION OF DETERMINANT OF LABOR MIGRATION

\begin{tabular}{|c|c|c|c|c|c|c|c|c|}
\hline \multirow[b]{2}{*}{ Variable } & \multirow[b]{2}{*}{$\beta_{i}$} & \multirow[b]{2}{*}{ S.E } & \multirow[b]{2}{*}{ Wal } & \multirow[b]{2}{*}{ df } & \multirow[b]{2}{*}{$\mathbf{S i}$} & \multirow{2}{*}{$\begin{array}{l}\mathbf{E x} \\
\mathbf{p} \\
\text { (B) }\end{array}$} & \multicolumn{2}{|c|}{$\begin{array}{c}95 \% \mathrm{CI} \\
\text { for } \operatorname{Exp}(B)\end{array}$} \\
\hline & & & & & & & Low & $\overline{\text { Up }}$ \\
\hline SEX & 0.0 & 0.2 & 0.0 & 1. & 0. & 1.0 & 0.6 & 1.5 \\
\hline AGE & 0.0 & 0.0 & 0.3 & 1. & 0. & 1.0 & 1.0 & 1.0 \\
\hline EDU & 0.1 & 0.2 & 0.4 & 1. & 0. & 1.1 & 0.8 & 1.5 \\
\hline DEBT & 0.0 & 0.0 & 1.3 & 1. & 0. & 1.0 & 1.0 & 1.0 \\
\hline STATUS & - & 0.3 & 3.6 & 1. & 0. & 0.6 & 0.4 & 1.0 \\
\hline UNEMPLO & 0.1 & 0.3 & 0.2 & 1. & 0. & 1.1 & 0.7 & 1.8 \\
\hline $\mathrm{INCOME}_{\mathrm{t}-1}$ & 0.0 & 0.0 & 6.7 & 1. & .0 & 1.0 & 1.0 & 1.0 \\
\hline INCOME & 0.0 & 0.0 & 0.4 & 1. & 0. & 1.0 & 1.0 & 1.0 \\
\hline
\end{tabular}




\begin{tabular}{lllllllll} 
EMPLOYR & 0.0 & 0.0 & 1.6 & 1. & 0. & 1.0 & 1.0 & 1.0 \\
ATTITUDE & - & 0.1 & 17.9 & 1. & .0 & 0.5 & 0.4 & 0.7 \\
OWNHOU & - & 0.2 & 11.3 & 1. & .0 & 0.4 & 0.3 & 0.7 \\
FAMMEM & 0.3 & 0.1 & 15.6 & 1. & .0 & 1.3 & 1.2 & 1.5 \\
DIFFICUL & 0.8 & 0.3 & 9.0 & 1. & .0 & 2.2 & 1.3 & 3.8 \\
UNEMPLO & 0.1 & 0.2 & 0.1 & 1. & 0. & 1.1 & 0.7 & 1.6 \\
POOR & 0.4 & 0.3 & 1.9 & 1. & 0. & 1.5 & 0.8 & 2.7 \\
LOWINCO & 0.6 & 4.3 & 0.0 & 1. & 0. & 1.9 & 0.0 & 8.2 \\
POLITIC & 0.4 & 0.5 & 0.7 & 1. & 0. & 1.5 & 0.5 & 4.4 \\
OPPORTU & - & 0.1 & 6.8 & 1. & .0 & 0.8 & 0.7 & 1.0 \\
WELFARE & - & 0.3 & 3.4 & 1. & 0. & 0.6 & 0.4 & 1.0 \\
POPDENS & 0.0 & 0.0 & 1.0 & 1. & 0. & 1.0 & 1.0 & 1.0 \\
NONFARM & 0.8 & 0.5 & 2.6 & 1. & 0. & 2.2 & 0.8 & 5.5 \\
GETJOB & 0.4 & 0.3 & 2.0 & 1. & 0. & 1.5 & 0.8 & 2.8 \\
CONSTAN & 0.7 & 2.3 & 0.1 & 1. & 0. & 1.9 & & \\
\hline \hline
\end{tabular}

Note: DISTANCE, DIFINCOM and AREA variables are leaved from the model. * is the significant at the 0.05 level.

TABLE VIII: FITTED MODEL OF VARIABLES IN THE EQUATION OF DETERMINANT OF LABOR MIGRATION

\begin{tabular}{lcc}
\hline & Full Model & Fitted Variables (Sig.<0.05) \\
& $\boldsymbol{\beta}_{\boldsymbol{i}}$ & $\boldsymbol{\beta}_{\boldsymbol{i}}$ \\
\hline SEX & -0.043 & \\
AGE & 0.009 & \\
EDU & 0.09 & \\
DEBT & 0 & \\
STATUS & -0.51 & $0.000^{*}$ \\
UNEMPLOY & 0.117 & \\
INCOME $\mathrm{t}-1$ & 0 & $-0.617^{*}$ \\
INCOME & 0 & $-0.798^{*}$ \\
EMPLOYRT & -0.006 & $0.362^{*}$ \\
ATTITUDE & -0.613 & $1.012^{*}$ \\
OWNHOUSE & -0.803 & \\
FAMMEMB & 0.283 & \\
\hline DIFFICULT & 0.806 & \\
UNEMPLOY $\mathrm{t}-1$ & 0.055 & \\
DRYWEAT & 1.93 & \\
POOR & 0.408 & $-0.213^{*}$ \\
LOWINCOM & 0.619 & \\
POLITIC & 0.435 & \\
OPPORTU & -0.196 & \\
WELFARE & -0.483 & \\
\hline DISTANCE & & \\
DIFINCOM & & \\
POPDENS & 0.009 & \\
AREA & & \\
NONFARM & 0.77 & \\
GETJOB & 0.424 & \\
CONSTANT & 0.657 & \\
\hline \hline
\end{tabular}

Table VIII present the fitted model of variables in the equation of determinant of labor migration. It illustrates that determinant of labor migration are INCOME $_{\mathrm{t}-1,}$ ATTITUDE, OWNHOUSE, FAMMEMB, DIFFICULT, and OPPORTU variables. Therefore, the determinant of migrant worker to migrate are income before migration of labor, knowledge and attitude toward destination, having own house at home, number of family member living in destination country, difficulties in finding work at home, and career achievement opportunities at home.

\section{CONCLUSION AND RECOMMENDATIONS}

This research has focused on the determinants of labor migration. The motives of migration come from various factors. The most important economic factors are wage difference. Thailand has the highest daily minimum wage around US\$ 9 per day. Thailand is therefore attracting a huge migration flow from neighboring migrants. The second economic factor which is motive of migration is the difference of the unemployment rate between sending country and destination. Thailand's unemployment rate hit a bottom. Economic growth is expected to be the third economic factor. Thailand's GDP per capita is highest among these countries. Other factors are geography and country's development. Since Thailand, Myanmar, Cambodia and Laos are located nearby; it is also the main motives of migration. Finally, human development index (HDI) plays a great role as well. Thailand's HDI rank at $83^{\text {th }}$ refer high human development group, follow by Lao PDR, Cambodia and Myanmar. In this study, it is observed that migrants are significantly 30 aged, more likely to be women and considerably graduate primary education. The analysis shows up that the migrants are more likely to be married and be employed. An increase of relative income of a migrant compared to prior migration by $235 \%$ (from 2,850 Baht per month to 9,554 Baht per month). The ratio of working family member to total family member is $75 \%$. The majority of them do not have own house at home country. The significant influence of number of family member living abroad is important for migration analysis. Most migrants have an average of three persons in their family living aboard. They mostly had background about the difficulties to find work at home country.

This paper recommends the policy for foreign workers. First, the migrants request about medical welfare. Only half of legally migrants join Thailand's social security fund. As a result, more than a million migrants are exclusive. Even government attempt to force the employer and employee by law, therefore, government should reconsider about the willingness to pay and the ability to pay of both sides. Second, a distinctive feature of Asia migration is the migrant prone to migrate in a group. A great number of children are neglecting around the construction camp without accessing to formal education. Government should concentrate on this issue since the increasing of crime rate. It may be significance for the social. Thus, government should supervise the fundamental education for migrant children. Third, the migrants express the opinion about the illegal workers fled into the country. It is the international issue and it has never endless. The destination country and the country of origin of migrant should coordinate to find out the solution. Fourth, the most requests by the migrants which are the talk of the town topic are the migrant want the government to reset the registration system to reduce step and time of registration. Besides, its cost should decrease because it is too high and most of them feel that it is unaffordable. According to the data from the Ministry of Labor in 2018, it was found that about 2 million people registered to work but there were still have about 800,000 foreign workers who have not yet completed their nationality verification according to the period of registration. This cause these foreign workers were an illegal worker, but employers and entrepreneurs still need to hire. The sending labor return to the country of origin according to legal measures may affect the labor shortage situation in the country. Hence, government should reset the system, cutting some processes, increasing the staff to administrative foreign 
worker fitting to the number of foreign worker, using computer and technology to manage the process, distributing the power to local government unit to do this work, allowing foreign workers to register throughout the year and saving cost of employer. Finally, the interpersonal relationship between boss and labor is sensitive issue that foreign workers are discussed. Many workers feel under being exploited, at the same time, many employer feel uncomfortable to stand on their employee. It is quite difficult to tune in for both parties to understand each other. Foreign workers will change their employer as hard as that the employer will change the employee. That is why, there should have the intermediate work agencies to work as the clearing house of labor demand and supply. Government should relax the migrant control policy. The migrant should feel free to change the work.

\section{CONFLICT OF INTEREST}

This submitted work was carried out without a conflict of interest. The authors declare no conflict of interest.

\section{AUTHOR CONTRIBUTIONS}

The author conducted the research; analyzed the data; wrote the paper; approved the final version.

\section{ACKNOWLEDGMENT}

The authors would like to thank Kasetsart University Research and Development Institute (KURDI), Kasetsart University, Thailand, for funding this research. In addition, the author also has a special thanks to all migrant workers from Myanmar, Cambodia and Lao for their kindness to participate the interview.

\section{REFERENCES}

[1] United Nation, International Migration Report, Highlights. Department of Economic and Social Affairs, United States: New York, 2017.
[2] United Nation. Thailand Migration Report, United Nation Thematic Working Group on Migration in Thailand, Thailand: Bangkok, 2019.

[3] World Bank. (2018). Bilateral estimates of migrant stocks in 2017 [Online]. Available: http://databank.worldbank.org/data

[4] Foreign Workers Administration Office. (2018). Statistic of foreign worker in Thailand. Ministry of Labor: Foreign Workers Administration Office. [Online]. Available: http://www.doe.go.th/alien

[5] Asian Development Bank, Migration in the Greater Mekong Subregion. A Background Paper for the Fourth Greater Mekong Subregion Development Dialogue. Asian Development Bank, Beijing, People's Republic of China, 2009.

[6] S. H. Walker and D. B. Duncun, "Estimation of the probability of an event as a function of several independent variables," Biometrika, vol. 54 , no. $1 / 2$, pp. $167-179,1967$.

Copyright (C) 2020 by the authors. This is an open access article distributed under the Creative Commons Attribution License which permits unrestricted use, distribution, and reproduction in any medium, provided the original work is properly cited (CC BY 4.0).

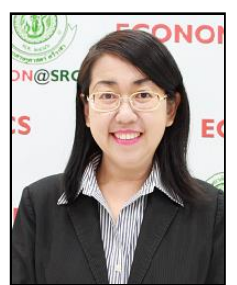

Thitiwan Sricharoen is a economist with $\mathrm{PhD}$ in agricultural economics. Present she is an associate professor of economics at Faculty of Economics at Sriracha, Kasetsart University, Sriracha Campus, Chonburi. She worked at Department of Economics, Faculty of Management Science, Khon Kaen University, Thailand for 15 years. According to educational qualification, she received her B.A. in economics in 1996 from Thammasat University, Thailand, M.A. in economics in 1998 from Chulalongkorn University, Thailand, Ph.D. in agricultural economics in 2007 from University of Hohenheim, Germany. She has more than 19 years of teaching and research experience. Her fields of specialization are international economics, development economics and agricultural economics. She is the author of books of International Trade Theory and Policy, Khon Kaen University Press, 2011, International Economic, Khon Kaen University Press, 2015. She has also published many research papers and articles in different national and international journals. Currently, Dr. Thitiwan Sricharoen researches focus on poverty, vulnerability measurement, elderly welfare arrangement, labor migration, impact of unemployment, micro insurance, pattern of paddy storage, and international economy. 